This manuscript is an EarthArXiv preprint and has not been peer-reviewed before.

Subsequent versions of this manuscript may have slightly different content.

\title{
Agricultural Flood Vulnerability Assessment and Risk Quantification in Iowa
}

\author{
Enes Yildirim ${ }^{\text {a, }}$, Ibrahim Demir ${ }^{\text {a,b }}$ \\ ${ }^{a}$ Department of Civil and Environmental Engineering, University of Iowa \\ ${ }^{\mathrm{b}}$ Department of Electrical and Computer Engineering, University of Iowa \\ * Corresponding Author, Contact: enes-yildirim@uiowa.edu
}

\begin{abstract}
Agricultural lands are often impacted by flooding, which results in economic losses and causes food insecurity across the world. Due to the world's growing population, land-use alteration is frequently practiced to meet global demand. However, land-use changes combined with climate change have resulted in extreme hydrological changes (i.e., flooding and drought) in many areas. The state of Iowa has experienced several flooding events over the last couple of decades (e.g., 1993, 2008, 2014, 2016, 2019). Also, agribusiness is conducted across 85 percent of the state. In this research, we present a comprehensive assessment for agricultural flood risk in the state of Iowa utilizing most up-to-date flood inundation maps and crop layer raster datasets. The study analyzes the seasonal variation of the statewide agricultural flood risk by focusing on corn, soybean, and alfalfa crops. It also investigates the crop frequency layers and corn suitability rating datasets to reveal regions with lower or higher productivity ratings. Additionally, a terrain-based flood model is used to analyze performance against the FEMA maps. The research discusses the potential mitigation activities for the most vulnerable watersheds in the state. The analysis shows that nearly a half-million acres of cornfields and soybean fields are located in the 2-year flood zone. We also found that terrain-based flood maps are a reliable alternative for agricultural flood risk assessment based on their dynamic structure, rapid update capability, and performance compared to FEMA maps.
\end{abstract}

Keywords: flood risk quantification, agricultural vulnerability, flood vulnerability, flood risk assessment, floods 
This manuscript is an EarthArXiv preprint and has not been peer-reviewed before.

Subsequent versions of this manuscript may have slightly different content.

\section{Introduction}

Flooding leads to excessive economic losses and severe environmental impacts (i.e., soil loss, contamination) on agricultural lands every year. Recent studies suggest that food security is under critical risk in numerous countries due to flooding (Del Ninno et al., 2003; Oskorouchi and SousaPoza, 2021; Balana et al., 2016; Vahedifard et al., 2016). On a global scale, flooding is ranked as the second driving factor resulting in livestock and crop production losses between 2008 to 2018 (FAO, 2021). The United States has experienced several devastating flooding events in urban and agricultural areas, leading the federal government creating the Federal Crop Insurance Program (FCIP) in 1938 to provide insurance for farmlands and reimburse for crop losses against natural disasters (i.e., flooding, drought) (Crane-Droesch et al., 2019). The Federal Crop Insurance Corporation (FCIC) insured almost four hundred thousand acres of farmland in 2020 (RMA, 2021). Over $\$ 8$ billion in crop loss is estimated, and nearly $\$ 2$ billion in federal relief funds have been distributed for the Midwest Flood of 1993 (Sarmiento and Miller, 2006). Climate change triggers extreme flooding events more frequently (Tripathi et al., 2014). Recent studies reveal that the magnitude and probability of extreme floods are forecasted to soar in agricultural regions (Slater et al., 2019; Mallakpour and Villarini, 2015; Slater and Villarini, 2016). Therefore, sustainable agriculture is challenged by constant flood risk (Beddington et al., 2012). Thus, investigating the underlying causes is essential for taking the required measures to overcome the risk.

Intensive land-use modification and climate change are contributing factors to hydrological alterations and extreme events (e.g., floods, droughts) in agricultural lands (Lee and Brody, 2018; Hazarika et al., 2015; Aich et al., 2016; Benito et al., 2010). However, land-use alteration has been widely practiced in many regions (Meyfroidt et al., 2013; Houghton et al., 2012; Borelli et al., 2017). The implication of land-use changes is highlighted in several studies to understand flooding impacts in the downstream regions (Wheater and Evans, 2009; Bruzzone, 2013). Although landuse changes contribute significantly to peak flows to downstream regions (Apollonio et al., 2016), less mature vegetation (Anderson et al., 2006) and tile drainage (Thomas, 2015) are found to be the primary reasons that cause downstream flooding due to agricultural practices. Even though flooding impacts on farmlands that are only prone to a greater magnitude of flooding events (e.g., 100-year, 200-year) can be reduced by practicing certain mitigations, the damage is inevitable for areas within the more frequent flood zones, such as 2-year and 5-year return period zones. Exploring potential flooding impacts and productivity levels of those farmlands can be helpful in decision making (Xu et al., 2020; Teague et al., 2021) and justifying further actions. These actions can be land preservation with a structural or non-structural measure or land acquisition to create wetlands or ponds.

\subsection{Agricultural Flood Risk Assessment}

Flood risk studies on agricultural lands produce valuable input for securing and maintaining food production for the world's growing population and understanding mitigation solutions for downstream regions. The benefits of the mitigation efforts can be effectively implemented by 
This manuscript is an EarthArXiv preprint and has not been peer-reviewed before.

Subsequent versions of this manuscript may have slightly different content.

prioritizing regions with up-to-date risk assessments (Yildirim, 2017; Alabbad et al., 2021). Agricultural flood risk assessments also aid in the application of mitigation decisions (Sermet et al., 2020), such as identifying agriculture fields to be removed from production (Tapia-Silva et al., 2011), land-use changes (Schilling et al., 2014), drainage networks (Gambolati et al., 2006), levees (Olson and Morton, 2012), dikes (Tran et al., 2018), and dam construction (Navarathinam et al, 2015). Because these mitigation practices are costly, a detailed flood risk assessment allows maximizing benefits to achieve feasible solutions (Yildirim and Demir, 2021). An ideal benefitcost analysis should include risk products as input to determine whether mitigation decisions may succeed or fail for the area of interest. Thus, datasets and models should be rigorously selected to provide accurate results. Then, the risk assessment can be conducted on a large scale to gain insight into the vulnerability of the area.

\subsection{Agricultural Loss Quantification}

Agricultural loss quantification often requires the latest datasets to provide the most recent crop risk for an area of interest. Accurately quantified losses can be helpful to support informed decisions for flood management (Haltas et al., 2021; Ewing and Demir, 2021). Recent developments in web systems and geospatial technologies (Agliamzanov et al., 2020; Sit et al., 2019) allow accessing and analyzing large-scale datasets (Ebert-Uphoff et al., 2017) like highresolution flood inundation maps, statewide agricultural land-use rasters, and property repositories. High-quality crop information and flood inundation data are essential for the accurate estimation of agricultural loss quantification. Although remote-sensing-based flood maps are utilized for loss quantification (Rahman et al., 2016), those datasets (e.g., soil moisture, flood map imagery) are prone to errors (Hornbuckle et al., 2017), leading to inaccurate estimations (Rahman and $\mathrm{Di}, 2019)$. On the other hand, a reliable estimate should include the proper dollar amount of inputs and outputs of crop production, such as the price of the year, the average harvest cost of the year, the average yield of the season, and government incentives (Downton and Pielke, 2005). The data requirements that we defined above must be satisfied for the agricultural loss quantification to minimize and eliminate errors. Thus, the quality and timeliness of the datasets determine the accuracy of the risk products, therefore, the mitigation decisions.

\subsection{Scope of the Research}

Understanding agricultural flood risk provides invaluable information to decision-makers as they plan mitigation efforts to reduce potential losses. However, the task requires substantial technical and domain knowledge, such as flood mapping, spatial data analysis, database management, and loss quantification methodologies (Yildirim and Demir, 2019). Conducting a large-scale agricultural flood loss assessment can reveal significant insights into prioritizing regions and supporting mitigation decisions. For Iowa, agricultural practices are an essential component of the state's economy; therefore, a statewide agricultural loss investigation is crucial to perceive potential risks. Because the major communities experienced several flood events in the past, potential mitigation efforts can be deduced from a large-scale risk assessment. Several studies have 
This manuscript is an EarthArXiv preprint and has not been peer-reviewed before.

Subsequent versions of this manuscript may have slightly different content.

been carried out at different scales (e.g., watershed, county, city) for the state of Iowa, such as Middle Cedar (Maroof, 2016; Antolini et al., 2020), North Racoon (Schilling et al., 2014), Freemont County (Crow, 2014), and Cedar Falls-Waterloo (West, 2010). However, these studies are rather limited to reflect the overall agricultural flood risk of the state. Because agriculture is intensively practiced across Iowa, a statewide risk assessment is critical to identify regions for potential mitigation applications.

This research proposes a comprehensive agricultural flood risk assessment for the state of Iowa. Nearly 25 million acres of agricultural land are analyzed with high-resolution statewide flood inundation maps. So, the results reveal the total acres of land that are located in different flood zones, for instance, 2-, 5-, 10-, 25-, 50-, 100-, 200-, and 500-year flood zones. The study investigates the seasonal variation (i.e., from 2016 to 2020) of the widely grown crop types (e.g., corn, soybeans, alfalfa) and highlights the vulnerable watersheds in the region. Additionally, crop frequency layers and corn suitability rating datasets are employed to understand future crop losses and analyze the productivity of regions prone to flooding. Thus, those regions can be prioritized for preserving farmlands or selected as potential mitigation sites to reduce urban flooding downstream. The results are generated on different watershed scales (hydrological unit code (HUC)-8 and HUC-12) to discuss the overview of the state and the most vulnerable regions. The study also investigates the performance of terrain-based flood model outputs for agricultural flood loss assessments. Therefore, a new data source can be explored for conducting agricultural flood risk assessments.

In the following sections, the methodology provides information about the study region, data sources, data processing, and agricultural loss quantification. In the results section, statewide agricultural losses, crop frequency layer analysis, and corn suitability rating analysis are presented. The section presents watershed-scale assessments for the most impacted regions. Additionally, a recently developed flood mapping model (a terrain-based model) is evaluated and compared to FEMA maps for agricultural flood loss analysis. In conclusion, key findings, challenges, and future work are presented.

\section{Methodology}

\subsection{Study Region}

The state of Iowa is located in the midwestern region of the United States between the Missouri and Mississippi rivers, as illustrated in Figure 1. The state also has three major streams namely the Cedar River, the Des Moines River, and the Iowa River. Several large communities are located on those rivers, such as Cedar Falls, Cedar Rapids, Des Moines, Iowa City, and Waterloo. The landscape is heavily altered by agriculture practices, primarily for corn and soybean farmlands. The state has nearly 13-million-acres of cornfields and 9 million-acres of soybean fields (NASS, 2020). Landscape alterations such as tile drainage and intensive agricultural land use lead to sedimentation (Xu et al., 2019) and hydrologic regime changes (i.e., higher peak flow frequency) in many watersheds throughout the region (Thomas, 2015; Wehmeyer et al., 2011). Iowa has experienced heavy flood losses in both urbanized and agricultural lands. Since 1953, 29 flood- 
related disaster declarations have been made for the state (FEMA, 2021). Over the last couple of decades, Iowa has been impacted by significant flood events (i.e., 1993, 2008, 2014, 2016, and 2019). The region is prone to extreme flood events for both urban and agricultural lands.

\subsection{Data Sources}

Statewide inundation maps developed by the Iowa Flood Center (Gilles et al., 2016) are utilized to carry out agricultural flood risk analysis. The Federal Emergency Management Agency (FEMA) and the United States Army Corps of Engineers (USACE) generated the inundation maps using high-resolution (1-meter) light detection and ranging (LiDAR) data. The USACE creates the inundation maps for the northwestern part of the state, and FEMA completes the remaining regions of the state. The maps are produced based on probability-based scenarios using the United States Geological Survey (USGS) historic gauge records to identify discharges for 2-year, 5-year, 10year, 25-year, 50-year, 100-year, 200-year, and 500-year events to feed the hydraulic model. In Figure 2, a 100-year flood scenario map is demonstrated for Iowa. The flood maps are reprojected, transformed, and stored on the PostgreSQL server for the analysis.

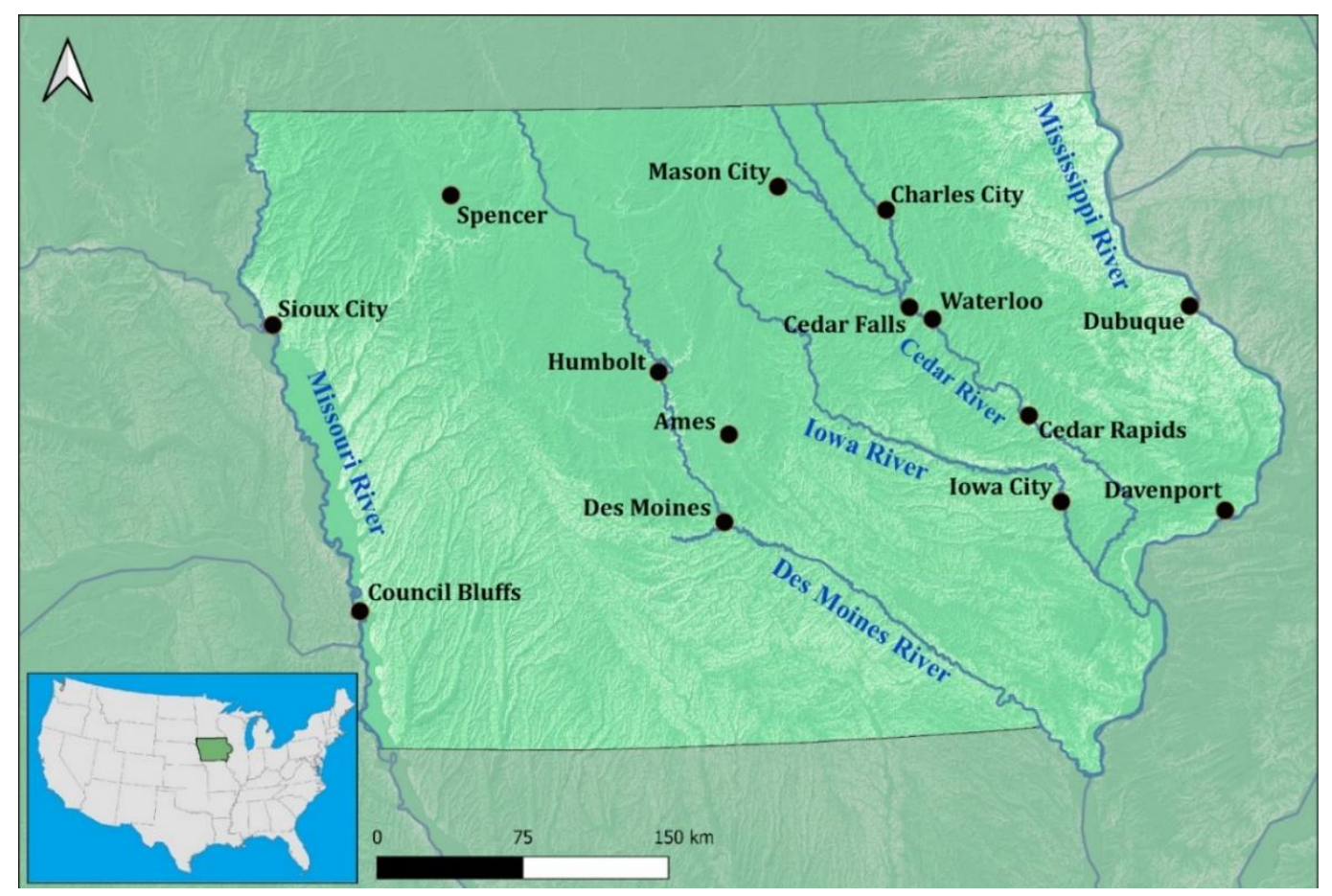

Figure 1. Major communities and streams in the study region

The National Agricultural Statistics Service (NASS) releases land cover datasets and other land classifications acquired using remote sensing technologies for the conterminous United States (Han et al., 2012). NASS made the dataset publicly available through a web-based system called "Cropland Data Layer" (CDL) (Johnston, 2013). We collected crop cover datasets for Iowa between 2016 to 2020 and crop frequency layers for corn and soybean crops through the CDL. 
The crop cover datasets include all crop types that are planted in the state within a specific year. For our analysis, we only consider alfalfa, corn, soybeans, sweet corn, and grassland. The crop frequency layers contain crop-specific (i.e., cotton, corn, soybean, and wheat) planting frequencies based on historical remotely sensed data (Boryan et al., 2014). Corn and soybean frequency layers are collected due to the dominant crop regime in the state. Frequency layers are stored in raster format in the PostgreSQL server.

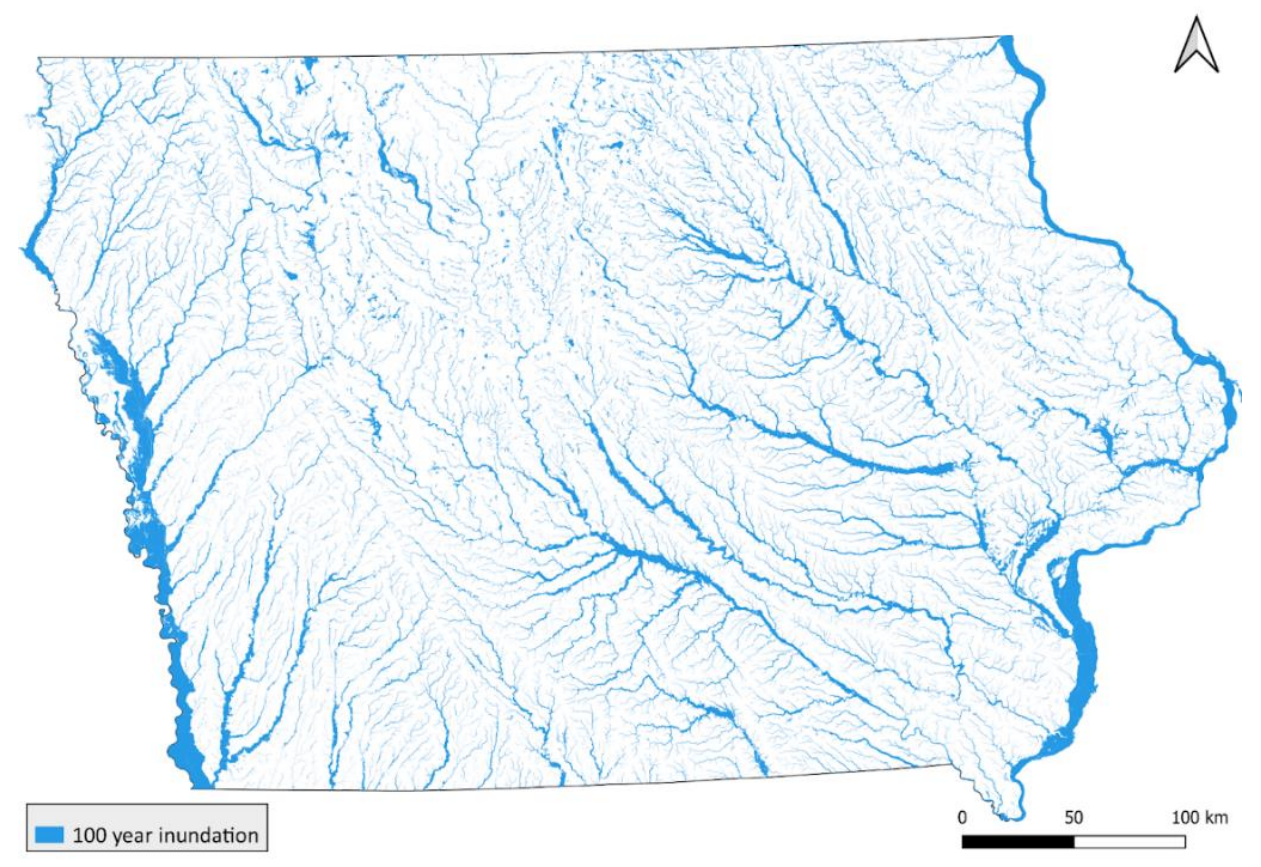

Figure 2. 100-year flood inundation map in Iowa

We also acquired the Corn Suitability Rating (CSR) from the SSURGO (Soil Survey Geographic database) dataset, which was created by the United States Department of Agriculture (USDA) Natural Resources Conservation Service (NRCS). SSURGO provides CSR, which indexes a land's productivity between 0 to 100 (Secchi et al., 2009). 100 means the land is very productive, and 0 means the land has poor productivity. The collected data layers are generated at a 30-meter resolution in a raster format, and they are stored on the PostgreSQL server for our analysis.

Crop yields, prices, harvest costs, and government incentive datasets are critical to quantifying agricultural losses. The USDA collects yields (USDA, 2021a; USDA, 2021b; USDA, 2021c; Johanns, 2021a), prices (Johanns, 2021b), costs (Plastina, 2021), and incentives (Plastina and Leibold, 2019; Plastina and Liebold, 2021) for alfalfa, the parameters like cost, price, and yield are used as static numbers for our estimations. However, these parameters are available on a yearly basis for corn and soybean crops in Iowa, so custom values are considered due to the variance in parameters such as farming seasons from 2016 to 2020 and geolocations (i.e., county). 
This manuscript is an EarthArXiv preprint and has not been peer-reviewed before.

Subsequent versions of this manuscript may have slightly different content.

\subsection{Data Processing}

In the study, we collected an extensive dataset for flood maps, land use rasters, CSR rasters, crop frequency layers, and crop yield/price/cost data to carry out a comprehensive agricultural flood impact assessment for the state. The datasets are handled in open-source databases, libraries, and geographic information systems (GIS) software such as QGIS, PostgreSQL, and PostGIS. Geographic datasets (i.e., flood maps, agricultural rasters) are reprojected to the Albers Equal Area projection because it preserves the area. So, underestimation or overestimation of the inundated agricultural area can be avoided. Using QGIS and its server connection to PostgreSQL, we reviewed data tables to ensure data distortion and missing regions were avoided in the study area. Due to the complexity of handling hundreds of data tables, we created a web service using PHP to migrate all data tables to the PostgreSQL server. Afterward, the database is designed to create a relational data model between our data tables and determine the data formats (i.e., integer, decimal, rast, geom). The following queries are optimized for estimating inundation areas and average annual losses. Figure 3 lays out the steps for the data processing workflow.

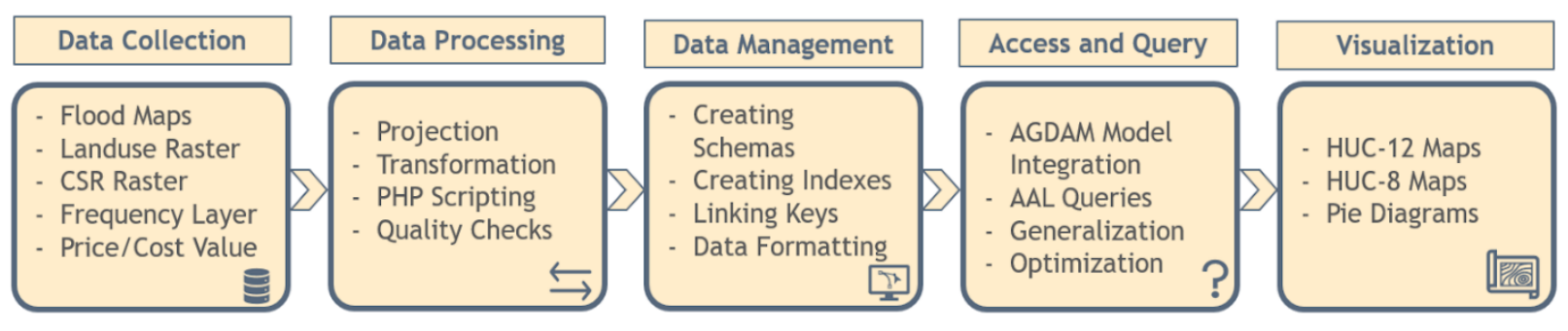

Figure 3. Data life cycle for agricultural flood loss assessment framework

Although existing software and tools are available to conduct agricultural flood impact (i.e., Hazard United States (HAZUS)), PostgreSQL, PostGIS, and PHP scripting allowed us to automate handling and processing large-scale datasets more efficiently. The Agricultural Flood Damage Analysis Model (AGDAM), which will be explained in the following section, is replicated using PostgreSQL queries. Additionally, the optimized queries are scalable to conduct flood impact analysis for other agricultural regions or analyze new datasets with few adjustments.

In the CSR and crop frequency data layers, raster histograms are utilized to reveal inundated areas in the study area. We classified the CSR raster into four groups based on the suitability rate percentile, such as greater than 80 percent, 80 to 60 percent, 60 to 40 percent, and 40 to 15 percent. The rate under 15 percent is subtracted from our analysis to avoid overestimating inundated agricultural areas because these regions are not farmlands. Similar to the CSR dataset, crop frequency layers are classified into three groups based on the consecutive times of planting the same crop. Finally, the results are visualized using Hydrologic Unit Code (HUC) at HUC-12 and HUC-8 level utilizing QGIS software. 
This manuscript is an EarthArXiv preprint and has not been peer-reviewed before.

Subsequent versions of this manuscript may have slightly different content.

\subsection{Agricultural Loss Quantification}

In the literature, several studies suggest that the duration and time of the year (Julian day) are the main factors in estimating agricultural losses (Morris and Hess, 1988; Dutta et al., 2003; Posthumus et al., 2009; Brémond et al., 2013). The AGDAM model is one of the most preferred models that considers flood duration and the time of year for agricultural flood loss quantification (Maroof, 2016). Therefore, we employed the AGDAM methodology to quantify agricultural losses due to floods. The USACE developed the methodology with the given function below (USACE, 1985):

$$
L_{s}=A(p \cdot Y-H) \cdot D(t) \cdot R(t)
$$

where "Ls" stands for loss (is USD) for a specific flood scenario, "A" is the inundated ag-land; "p" is the unit price of the crop (price per bushel); " $\mathrm{Y}$ " is for the crop yield (bushels per acre); " $\mathrm{H}$ " is the harvest cost (\$ per acre); "D" is crop loss at the "t" day, and "R" is a crop loss modifier based on the flood duration. Each crop type's unique loss function indicates crop loss for a given time of the year and flood duration modifier. In this study, three different time of the year are selected to estimate losses based on crop growth. For instance, May 15, June 15, and July 15 are selected for corn and soybean crops to estimate low, medium, and high losses, respectively. Additionally, the loss analysis is conducted considering three-day and seven-day flood durations. We stored the functions in the PostgreSQL database for the agricultural loss estimation calculations.

Using the AGDAM model, agricultural flood losses are estimated in eight flood scenarios: 2-, 5-, 10-, 25-, 50-, 100-, 200-, and 500-year return period floods. Then, we estimated the average annual loss (AAL) in the HUC-12 watershed level using the following equation:

$$
\begin{aligned}
& A A L=L_{500} P_{500}+\left(P_{500}-P_{200}\right)\left(\frac{L_{500}+L_{200}}{2}\right)+\left(P_{200}-P_{100}\right)\left(\frac{L_{200}+L_{100}}{2}\right) \\
& +\left(P_{100}-P_{50}\right)\left(\frac{L_{100}+L_{50}}{2}\right)+\left(P_{50}-P_{25}\right)\left(\frac{L_{50}+L_{25}}{2}\right)+\left(P_{25}-P_{10}\right)\left(\frac{L_{25}+L_{10}}{2}\right) \\
& +\left(P_{10}-P_{5}\right)\left(\frac{L_{10}+L_{5}}{2}\right)+\left(P_{5}-P_{2}\right)\left(\frac{L_{5}+L_{2}}{2}\right)
\end{aligned}
$$

AAL is significant to reveal the risk for the studied region. So, we estimated AAL based on land use from 2016 to 2020 for corn, soybean, alfalfa, and sweet corn. After estimating the losses for every HUC-12 watershed, the results are aggregated to HUC-8 level watersheds for visualization and communication.

\section{Results \& Discussion}

In this study, agricultural flood risk assessments were conducted for nearly 25 million acres of agricultural land in the state of Iowa. Because corn and soybean crops are dominant in the region, we used land use data from the previous five years for those crops to investigate seasonal variation 
This manuscript is an EarthArXiv preprint and has not been peer-reviewed before.

Subsequent versions of this manuscript may have slightly different content.

in flooding impacts. Alfalfa and sweet corn layers are also extracted from the Cropland Data Layer to analyze flood risk for these crops. AALs are estimated for the HUC-12 watershed level using probability-based scenarios for each crop type. The HUC-12 scale AALs are aggregated to the HUC-8 watershed level to deliver the flood risk overview for the whole state.

Table 1. Impacted agricultural area based on probabilistic flood scenarios (acre)

\begin{tabular}{|c|c|c|c|c|c|c|c|c|c|c|}
\hline & Year & $2-y r$ & $5-y r$ & $10-y r$ & 25-yr & $50-y r$ & $100-y r$ & 200-yr & $500-y r$ & Total \\
\hline \multirow{5}{*}{ Alfalfa } & 2016 & $8 \mathrm{k}$ & $13 \mathrm{k}$ & $17 \mathrm{k}$ & $21 \mathrm{k}$ & $23 \mathrm{k}$ & $26 \mathrm{k}$ & $28 \mathrm{k}$ & $31 \mathrm{k}$ & $779 \mathrm{k}$ \\
\hline & 2017 & $3 \mathrm{k}$ & $7 \mathrm{k}$ & $10 \mathrm{k}$ & $13 \mathrm{k}$ & $14 \mathrm{k}$ & $16 \mathrm{k}$ & $18 \mathrm{k}$ & $20 \mathrm{k}$ & $665 \mathrm{k}$ \\
\hline & 2018 & $4 \mathrm{k}$ & $9 \mathrm{k}$ & $11 \mathrm{k}$ & $14 \mathrm{k}$ & $16 \mathrm{k}$ & $19 \mathrm{k}$ & $19 \mathrm{k}$ & $22 \mathrm{k}$ & $693 \mathrm{k}$ \\
\hline & 2019 & $4 \mathrm{k}$ & $8 \mathrm{k}$ & $10 \mathrm{k}$ & $13 \mathrm{k}$ & $14 \mathrm{k}$ & $18 \mathrm{k}$ & $18 \mathrm{k}$ & $21 \mathrm{k}$ & $682 \mathrm{k}$ \\
\hline & 2020 & $6 \mathrm{k}$ & $11 \mathrm{k}$ & $15 \mathrm{k}$ & $19 \mathrm{k}$ & $20 \mathrm{k}$ & $25 \mathrm{k}$ & $25 \mathrm{k}$ & $29 \mathrm{k}$ & $734 \mathrm{k}$ \\
\hline \multirow{5}{*}{ Corn } & 2016 & $281 \mathrm{k}$ & $531 \mathrm{k}$ & $686 \mathrm{k}$ & $879 \mathrm{k}$ & $958 \mathrm{k}$ & $1,175 \mathrm{k}$ & $1,307 \mathrm{k}$ & $1,504 \mathrm{k}$ & $17.0 \mathrm{M}$ \\
\hline & 2017 & $271 \mathrm{k}$ & $515 \mathrm{k}$ & $664 \mathrm{k}$ & $851 \mathrm{k}$ & $927 \mathrm{k}$ & $1,139 \mathrm{k}$ & $1,269 \mathrm{k}$ & $1,459 \mathrm{k}$ & $16.5 \mathrm{M}$ \\
\hline & 2018 & $268 \mathrm{k}$ & $506 \mathrm{k}$ & $655 \mathrm{k}$ & $838 \mathrm{k}$ & $914 \mathrm{k}$ & $1,120 \mathrm{k}$ & $1,244 \mathrm{k}$ & $1,432 \mathrm{k}$ & $16.3 \mathrm{M}$ \\
\hline & 2019 & $253 \mathrm{k}$ & $488 \mathrm{k}$ & $630 \mathrm{k}$ & $815 \mathrm{k}$ & $885 \mathrm{k}$ & $1,095 \mathrm{k}$ & $1,122 \mathrm{k}$ & $1,318 \mathrm{k}$ & $17.0 \mathrm{M}$ \\
\hline & 2020 & $280 \mathrm{k}$ & $529 \mathrm{k}$ & $686 \mathrm{k}$ & $878 \mathrm{k}$ & $955 \mathrm{k}$ & $1,172 \mathrm{k}$ & $1,291 \mathrm{k}$ & $1,489 \mathrm{k}$ & $17.2 \mathrm{M}$ \\
\hline \multirow{5}{*}{ Grassland } & 2016 & $266 \mathrm{k}$ & $437 \mathrm{k}$ & $526 \mathrm{k}$ & $631 \mathrm{k}$ & $657 \mathrm{k}$ & $743 \mathrm{k}$ & $748 \mathrm{k}$ & $815 \mathrm{k}$ & $7.43 \mathrm{M}$ \\
\hline & 2017 & $259 \mathrm{k}$ & $426 \mathrm{k}$ & $512 \mathrm{k}$ & $614 \mathrm{k}$ & $639 \mathrm{k}$ & $723 \mathrm{k}$ & $727 \mathrm{k}$ & $791 \mathrm{k}$ & $6.98 \mathrm{M}$ \\
\hline & 2018 & $240 \mathrm{k}$ & $398 \mathrm{k}$ & $481 \mathrm{k}$ & $579 \mathrm{k}$ & $605 \mathrm{k}$ & $686 \mathrm{k}$ & $687 \mathrm{k}$ & $751 \mathrm{k}$ & $6.83 \mathrm{M}$ \\
\hline & 2019 & $198 \mathrm{k}$ & $331 \mathrm{k}$ & $402 \mathrm{k}$ & $488 \mathrm{k}$ & $511 \mathrm{k}$ & $582 \mathrm{k}$ & $587 \mathrm{k}$ & $643 \mathrm{k}$ & $6.59 \mathrm{M}$ \\
\hline & 2020 & $199 \mathrm{k}$ & $333 k$ & $404 \mathrm{k}$ & $490 \mathrm{k}$ & $514 \mathrm{k}$ & $586 \mathrm{k}$ & $588 \mathrm{k}$ & $646 \mathrm{k}$ & $6.50 \mathrm{M}$ \\
\hline \multirow{5}{*}{ Soybean } & 2016 & $152 \mathrm{k}$ & $298 \mathrm{k}$ & $390 \mathrm{k}$ & $500 \mathrm{k}$ & $556 \mathrm{k}$ & $696 \mathrm{k}$ & $822 \mathrm{k}$ & $953 \mathrm{k}$ & $11.8 \mathrm{M}$ \\
\hline & 2017 & $169 \mathrm{k}$ & $326 \mathrm{k}$ & $428 \mathrm{k}$ & $545 \mathrm{k}$ & $606 \mathrm{k}$ & $754 \mathrm{k}$ & $882 \mathrm{k}$ & $1,023 \mathrm{k}$ & $16.5 \mathrm{M}$ \\
\hline & 2018 & $168 \mathrm{k}$ & $329 \mathrm{k}$ & $431 \mathrm{k}$ & $552 \mathrm{k}$ & $612 \mathrm{k}$ & $766 \mathrm{k}$ & $901 \mathrm{k}$ & $1,045 \mathrm{k}$ & $12.8 \mathrm{M}$ \\
\hline & 2019 & $149 \mathrm{k}$ & $293 \mathrm{k}$ & $384 \mathrm{k}$ & $498 \mathrm{k}$ & $550 \mathrm{k}$ & $692 \mathrm{k}$ & $725 \mathrm{k}$ & $859 \mathrm{k}$ & $11.8 \mathrm{M}$ \\
\hline & 2020 & $153 \mathrm{k}$ & $304 \mathrm{k}$ & $398 \mathrm{k}$ & $513 \mathrm{k}$ & $571 \mathrm{k}$ & $717 \mathrm{k}$ & $841 \mathrm{k}$ & $976 \mathrm{k}$ & $12.3 \mathrm{M}$ \\
\hline \multirow{5}{*}{$\begin{array}{l}\text { Sweet } \\
\text { Corn }\end{array}$} & 2016 & 91 & 192 & 247 & 349 & 362 & 437 & 548 & 456 & $11 \mathrm{k}$ \\
\hline & 2017 & N/A & N/A & N/A & N/A & N/A & N/A & N/A & N/A & N/A \\
\hline & 2018 & N/A & N/A & N/A & N/A & N/A & N/A & N/A & N/A & N/A \\
\hline & 2019 & 17 & 33 & 45 & 62 & 72 & 83 & 104 & 118 & $6 \mathrm{k}$ \\
\hline & 2020 & 11 & 20 & 27 & 37 & 40 & 51 & 62 & 64 & $7 \mathrm{k}$ \\
\hline
\end{tabular}


This manuscript is an EarthArXiv preprint and has not been peer-reviewed before.

Subsequent versions of this manuscript may have slightly different content.

In Table 1, inundation area estimates are provided for alfalfa, corn, grassland, soybeans, and sweet corn with eight probability-based flood scenarios. Table 2 shows the inundated area ratio to the total area for a specific crop type. Corn has the highest inundation area compared to other crop types in all years and in all flood scenarios. Corn is also found to have the largest area within the flood zones for each scenario. The second most inundated land use is grassland. However, a flood loss estimate was not performed for grassland. Because grasslands are one of the most dominant land-use types in the state, we estimated the inundation area for each year and scenario to reflect the potential flooding impact on a major land use type.

Table 2. Inundated area rates for crop types using probability-based scenarios (percentage)

\begin{tabular}{|c|c|c|c|c|c|c|c|c|c|}
\hline & Year & $2-y r$ & $5-y r$ & $10-y r$ & 25-yr & $50-y r$ & $100-y r$ & 200-yr & $500-y r$ \\
\hline \multirow{5}{*}{ Alfalfa } & 2016 & 1.03 & 1.67 & 2.18 & 2.70 & 2.95 & 3.34 & 3.59 & 3.98 \\
\hline & 2017 & 0.45 & 1.05 & 1.50 & 1.95 & 2.11 & 2.41 & 2.71 & 3.01 \\
\hline & 2018 & 0.58 & 1.30 & 1.59 & 2.02 & 2.31 & 2.74 & 2.74 & 3.17 \\
\hline & 2019 & 0.59 & 1.17 & 1.47 & 1.91 & 2.05 & 2.64 & 2.64 & 3.08 \\
\hline & 2020 & 0.82 & 1.50 & 2.04 & 2.59 & 2.72 & 3.41 & 3.41 & 3.95 \\
\hline \multirow{5}{*}{ Corn } & 2016 & 1.65 & 3.12 & 4.03 & 5.16 & 5.62 & 6.90 & 7.67 & 8.83 \\
\hline & 2017 & 1.64 & 3.13 & 4.03 & 5.16 & 5.63 & 6.91 & 7.70 & 8.85 \\
\hline & 2018 & 1.65 & 3.11 & 4.03 & 5.16 & 5.62 & 6.89 & 7.65 & 8.81 \\
\hline & 2019 & 1.49 & 2.87 & 3.71 & 4.80 & 5.21 & 6.44 & 6.60 & 7.76 \\
\hline & 2020 & 1.62 & 3.07 & 3.98 & 5.09 & 5.54 & 6.80 & 7.49 & 8.64 \\
\hline \multirow{5}{*}{ Grassland } & 2016 & 3.58 & 5.88 & 7.08 & 8.49 & 8.84 & 9.99 & 10.06 & 10.96 \\
\hline & 2017 & 3.71 & 6.10 & 7.33 & 8.80 & 9.15 & 10.36 & 10.41 & 11.33 \\
\hline & 2018 & 3.51 & 5.82 & 7.04 & 8.47 & 8.85 & 10.04 & 10.05 & 10.99 \\
\hline & 2019 & 3.01 & 5.02 & 6.10 & 7.41 & 7.76 & 8.83 & 8.91 & 9.76 \\
\hline & 2020 & 3.06 & 5.12 & 6.21 & 7.54 & 7.91 & 9.01 & 9.04 & 9.94 \\
\hline \multirow{5}{*}{ Soybean } & 2016 & 1.29 & 2.53 & 3.31 & 4.24 & 4.71 & 5.90 & 6.97 & 8.08 \\
\hline & 2017 & 1.03 & 1.98 & 2.60 & 3.31 & 3.68 & 4.58 & 5.35 & 6.21 \\
\hline & 2018 & 1.31 & 2.57 & 3.37 & 4.32 & 4.79 & 5.99 & 7.05 & 8.17 \\
\hline & 2019 & 1.26 & 2.48 & 3.25 & 4.21 & 4.65 & 5.85 & 6.13 & 7.26 \\
\hline & 2020 & 1.24 & 2.47 & 3.24 & 4.17 & 4.64 & 5.83 & 6.84 & 7.94 \\
\hline \multirow{5}{*}{$\begin{array}{l}\text { Sweet } \\
\text { Corn }\end{array}$} & 2016 & 0.83 & 1.75 & 2.25 & 3.17 & 3.29 & 3.97 & 4.98 & 4.15 \\
\hline & 2017 & N/A & N/A & N/A & N/A & N/A & N/A & N/A & N/A \\
\hline & 2018 & $\mathrm{~N} / \mathrm{A}$ & N/A & $\mathrm{N} / \mathrm{A}$ & $\mathrm{N} / \mathrm{A}$ & N/A & $\mathrm{N} / \mathrm{A}$ & $\mathrm{N} / \mathrm{A}$ & N/A \\
\hline & 2019 & 0.28 & 0.55 & 0.75 & 1.03 & 1.20 & 1.38 & 1.73 & 1.97 \\
\hline & 2020 & 0.16 & 0.29 & 0.39 & 0.53 & 0.57 & 0.73 & 0.89 & 0.91 \\
\hline
\end{tabular}


This manuscript is an EarthArXiv preprint and has not been peer-reviewed before.

Subsequent versions of this manuscript may have slightly different content.

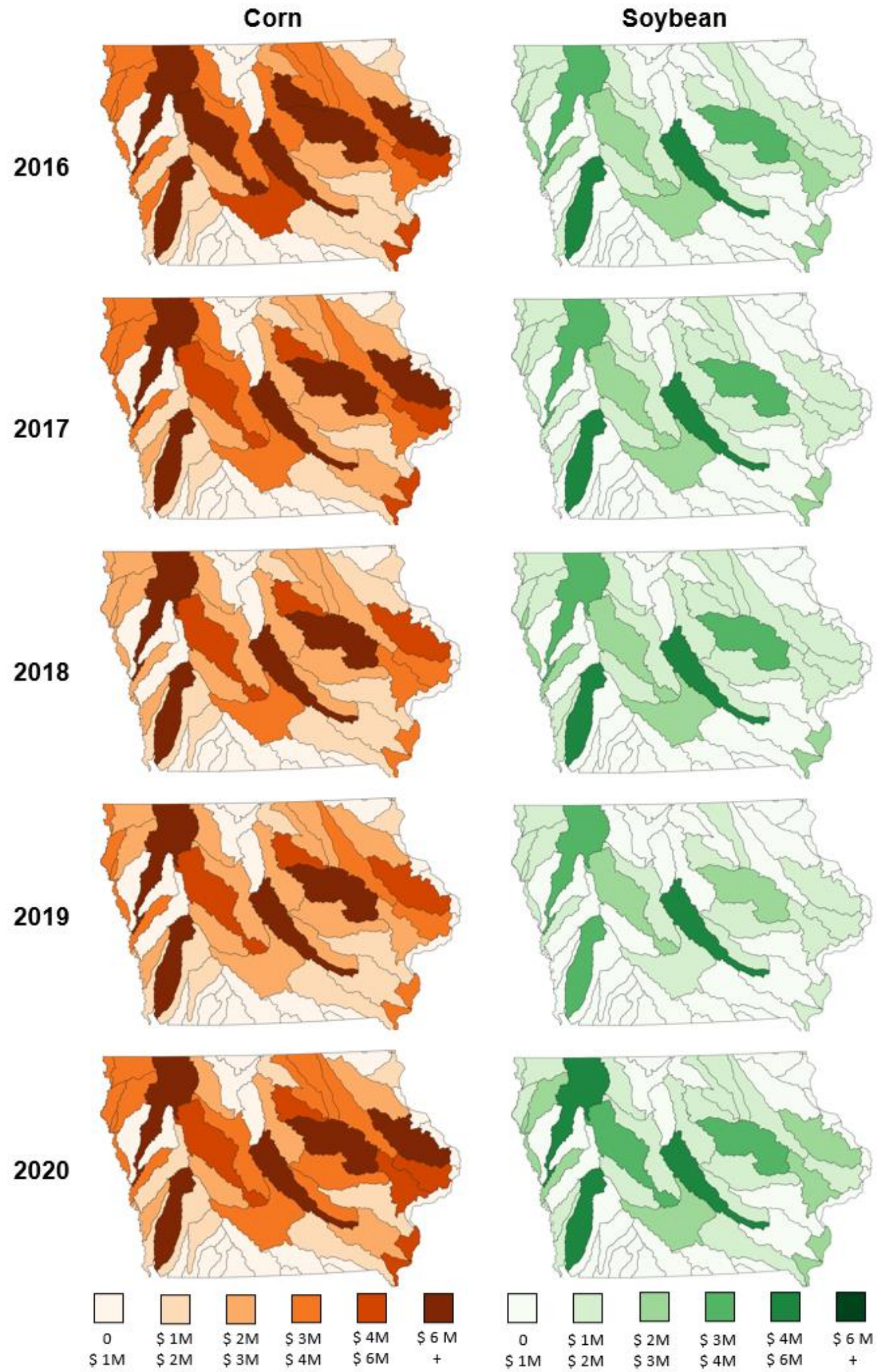

Figure 4. Estimated AAL in 3 days duration flood for corn and soybean 2016 to 2020 
Sweet corn is estimated as the least inundated crop type. Due to the lower inundation area, we combined AAL estimates for sweet corn with the corn crop for the statewide loss assessment. Inundation areas slightly change for each crop type in all years at the statewide evaluation. The inundated area ratio also remains almost the same for each crop type in all years (see Table 2). An overview of flood risk assessment for corn, soybean, and alfalfa crops is given at the HUC-8 scale in the following section. Then, we discussed CSR and crop frequency layer analysis at the statewide scale, and reflected on the most vulnerable watersheds. In the final analysis, a detailed risk assessment of the most impacted watersheds is evaluated by considering corn suitability ratings.

\subsection{Statewide Agricultural Flood Risk}

We conducted a statewide agricultural flood risk assessment for corn, soybean, and alfalfa crops using land-use data from 2016 to 2020 . The outlining reason for selecting multiple years is to understand whether the losses vary from season to season or not. Our analysis indicates only slight changes in estimated losses for corn and soybean crops in the state (see Figure 4). There is a homogenous estimated loss distribution within the HUC- 8 watershed level. In particular, some of the watersheds are prone to more flood losses, such as the Skunk River watershed (central Iowa), North Racoon watershed (central Iowa), Middle Cedar watershed (Eastern Iowa), and West Nishnabotna watershed (Southwestern Iowa). Except for West Nishnabotna, the majority of these watersheds have a large scale stream running through them. However, the AAL is also estimated to be high for the watershed.

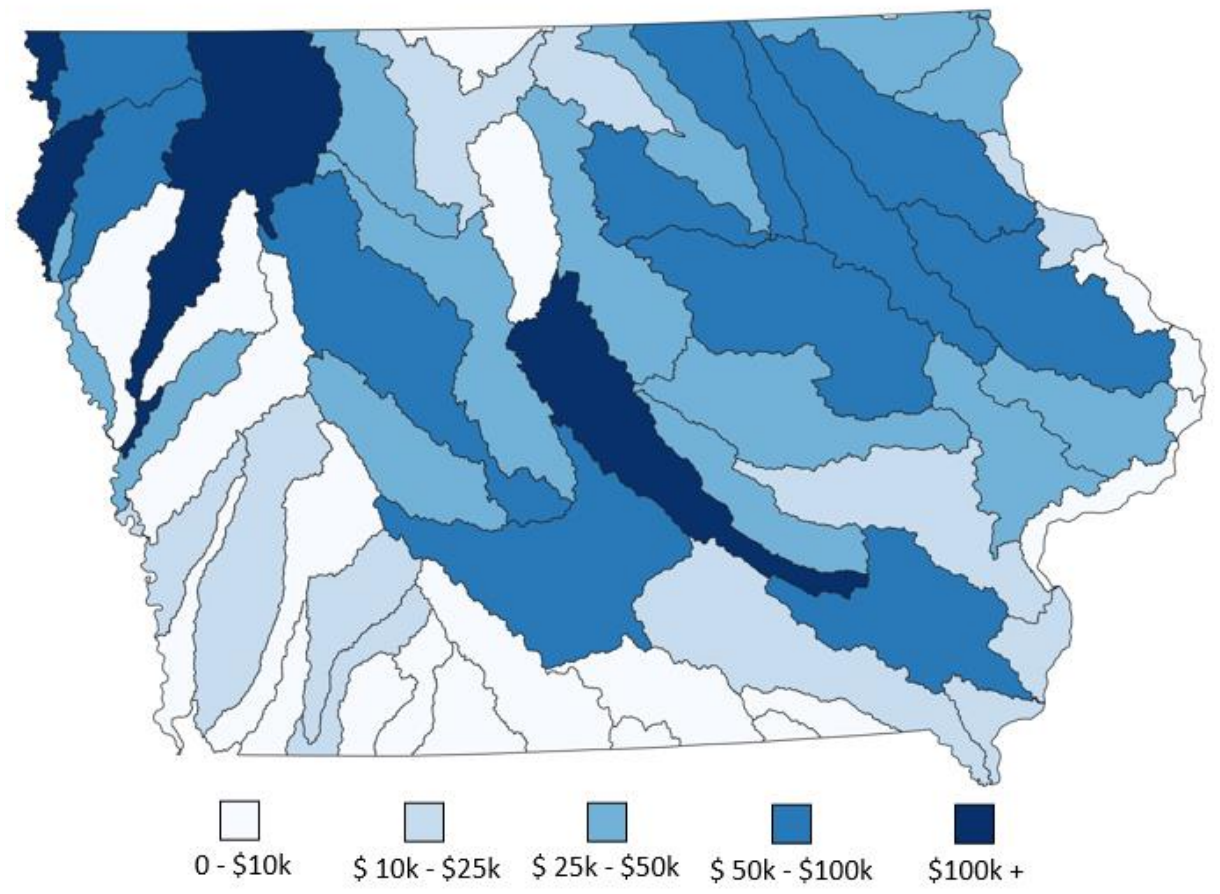

Figure 5. Estimated AAL in 3 days duration flood for alfalfa in 2020 
This manuscript is an EarthArXiv preprint and has not been peer-reviewed before.

Subsequent versions of this manuscript may have slightly different content.

Regarding corn losses, average annual loss (AAL) estimates reach more than $\$ 6$ million with the highest AAL estimate for soybeans is over $\$ 4.5$ million. Although corn and soybean crops are impacted at different levels, the most vulnerable regions are the same for both of these analyses. In addition, some large communities are located within those regions (i.e., Cedar Rapids, Cedar Falls, Des Moines, Waterloo). In the following section, we will discuss analysis for these regions in details.

Alfalfa is at the top five preferred crop types in Iowa, but it has a significantly lower land area compared to corn and soybean. Therefore, the AAL for alfalfa is estimated to be very low compared to other crop types. The highest loss is estimated at just over a hundred thousand US dollars for a watershed in central Iowa. The spatial distribution of the losses is very similar to corn and soybeans, with a slight variation. In Figure 5, AALs for alfalfa are demonstrated for the year 2020 land use data.

\subsection{Crop Frequency and CSR Analysis}

Crop frequency and corn suitability rating (CSR) datasets are analyzed with the statewide flood inundation maps in the study. One of the objectives for the analysis is to investigate potential mitigation options and identify the regions that may require protection from the potential flooding impact. Quantifying the regions where productivity is considerably lower than other regions can be an input for decisions like putting farm fields out of production or wetland restoration for mitigation efforts. In contrast, in higher productivity areas with higher flooding risks, quantification can aid in the protection of fertile farmlands. On the other hand, crop frequency data provides insights into future crop choices in farmlands (Boryan, 2014).

Table 3. Distribution of the corn and soybean fields that are constantly under risk based on crop frequency data (mile square)

\begin{tabular}{rcrrrrrrrr}
\hline & Frequency Range & 2-yr & $\mathbf{5 - y r}$ & $\mathbf{1 0}-\mathbf{y r}$ & $\mathbf{2 5}-\mathbf{y r}$ & $\mathbf{5 0 - y r}$ & $\mathbf{1 0 0}-\mathbf{y r}$ & $\mathbf{2 0 0}-\mathbf{y r}$ & $\mathbf{5 0 0}-\mathbf{y r}$ \\
\hline \multirow{4}{*}{ Corn } & $>9$ & 110 & 210 & 270 & 360 & 380 & 450 & 460 & 520 \\
& $6-9$ & 500 & 950 & 1,230 & 1,590 & 1,750 & 2,530 & 2,180 & 2,940 \\
& $<6$ & 340 & 550 & 660 & 790 & 850 & 1,160 & 980 & 1,270 \\
& Total & 940 & 1,710 & 2,160 & 2,740 & 2,980 & 4,150 & 3,620 & 4,740 \\
\multirow{4}{*}{ Soybean } & $>9$ & 0 & 0 & 0 & 0 & 10 & 10 & 10 & 10 \\
& $6-9$ & 290 & 580 & 760 & 980 & 1,100 & 1,680 & 1,400 & 1,980 \\
& $<6$ & 480 & 870 & 1,090 & 1,380 & 1,490 & 2,000 & 1,780 & 2,250 \\
& Total & 780 & 1,450 & 1,850 & 2,370 & 2,600 & 3,690 & 3,190 & 4,250 \\
\hline
\end{tabular}

We found that the 2-year flood zone is frequently utilized for agricultural purposes, particularly for corn farming (See Table 3). Therefore, mitigation efforts may be needed to reduce potential flooding impacts for the region. At this point, CSR can be a vital resource to analyze with flood maps to support mitigation decisions. Our analysis shows that nearly two thousand square miles 
This manuscript is an EarthArXiv preprint and has not been peer-reviewed before.

Subsequent versions of this manuscript may have slightly different content.

of farmland with a CSR of between $15 \%$ and $40 \%$ is within the 2-year flood zone (See Table 4). In addition, more than three thousand square miles of land in the 2-year flood zone has a CSR greater than $80 \%$. In the next section, the CSR analysis is discussed for the most vulnerable watersheds on a HUC-12 scale.

Table 4. Economic impact variability of the cornfields based on corn suitability rating (CSR) and FEMA flood maps (mile square)

\begin{tabular}{ccccccccc}
\hline CSR Ratio & $\mathbf{2 - y r}$ & $\mathbf{5 - y r}$ & $\mathbf{1 0}-\mathbf{y r}$ & $\mathbf{2 5}-\mathbf{y r}$ & $\mathbf{5 0 - y r}$ & $\mathbf{1 0 0}-\mathbf{y r}$ & $\mathbf{2 0 0}-\mathbf{y r}$ & $\mathbf{5 0 0}-\mathbf{y r}$ \\
\hline$>80 \%$ & 3,300 & 6,000 & 7,600 & 9,500 & 10,600 & 13,400 & 13,400 & 16,000 \\
$60-80 \%$ & 7,100 & 12,400 & 15,400 & 18,500 & 19,900 & 24,000 & 23,000 & 26,800 \\
$40-60 \%$ & 1,800 & 3,400 & 4,400 & 5,800 & 6,000 & 10,300 & 7,300 & 11,100 \\
$15-40 \%$ & 1,700 & 2,500 & 3,000 & 3,500 & 3,600 & 4,100 & 4,100 & 4,300 \\
Total & 13,900 & 24,300 & 30,300 & 37,300 & 40,100 & 51,800 & 47,800 & 58,300 \\
\hline
\end{tabular}

\subsection{Watershed-level CSR Analysis}

This section provides a detailed corn suitability rating analysis for the most vulnerable four watersheds: Middle Cedar, West Nishnabotna, North Racoon, and Skunk River watersheds. Average annual losses for 2-year and 5-year floods are provided along with the CSR information for each HUC-12 watershed. As described previously, CSR is grouped into four parts. The first group is the ratio greater than 80 percent (represented as red in Figure 6), between 60 to 80 percent (represented as orange), 40 to 60 percent (represented as yellow), and 15 to 40 percent (represented as green). For each group, an inundated area is estimated for a specific scenario (i.e., 2-year, 5year). The area is divided into the total estimated inundated area to reflect the percentage of each group.

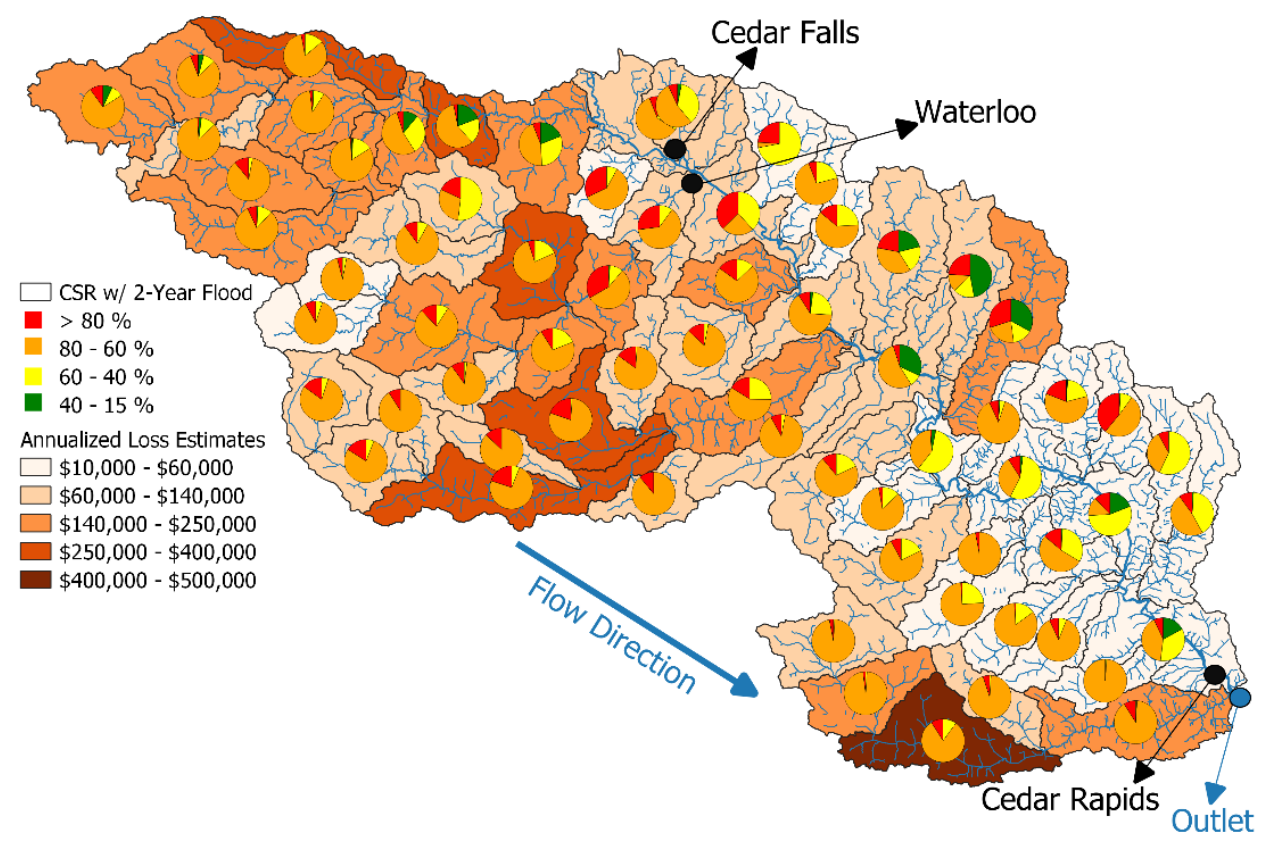




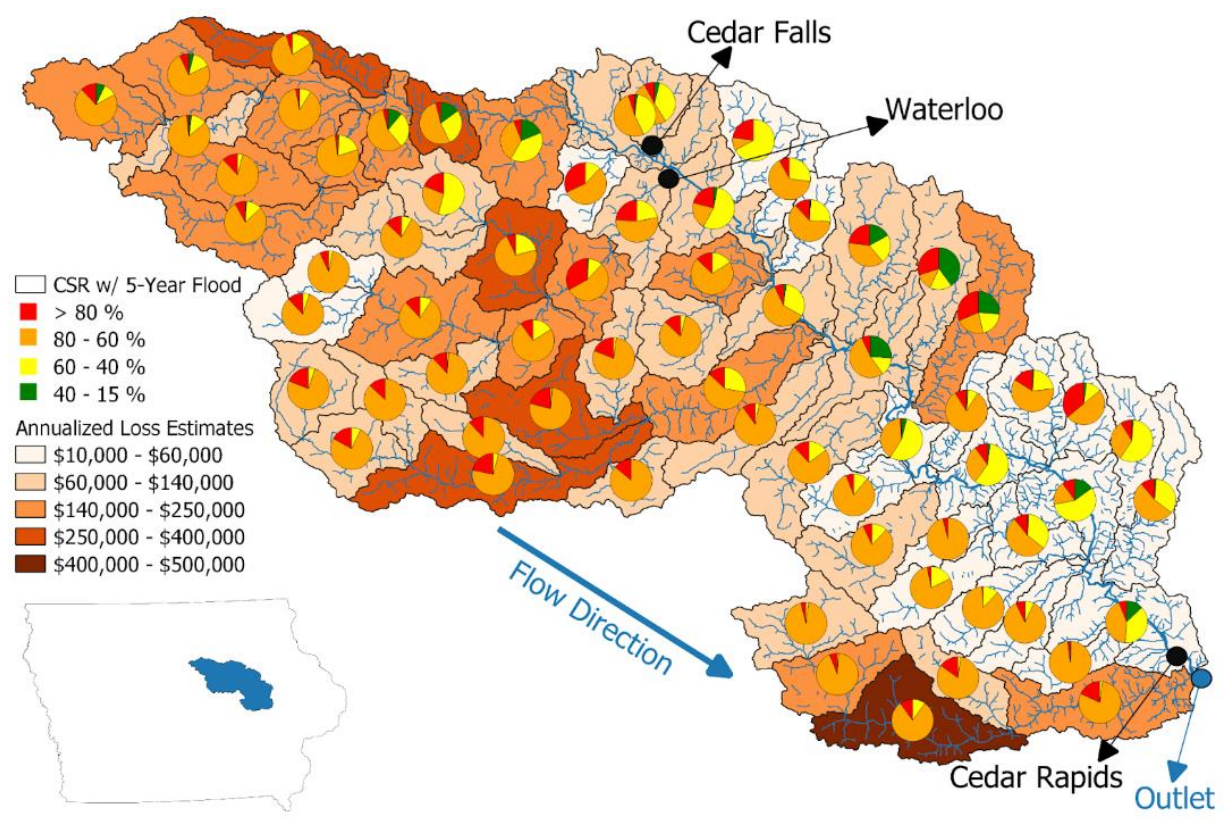

Figure 6. Distribution of CSR for 2- and 5- year flood scenario in Middle Cedar watershed

In Figure 6, AAL and CSR distribution are provided with 2-year and 5-year flood scenarios in the Middle Cedar watershed (Eastern Iowa). Three major cities that have experienced flooding several times are located within the watershed. Larger AALs are mostly estimated for the upstream part of the watershed. In both scenarios, the majority of HUC-12s have a CSR of 60 to $80 \%$. However, some of the HUC-12s have lower CSR in the northern part, where they also have higher AAL estimates. Further study is needed to reveal the potential mitigation opportunities beneficial to major cities in the region for mitigating urban flooding.

The North Racoon watershed is similar to the Middle Cedar watershed in that it includes a large community, Des Moines which is the capital of the state. The city was impacted by significant flooding events many times in the past decades (i.e., in 1993, 2008, and 2014). Estimated AAL reaches nearly a quarter-million US dollars in some of the HUC-12s in the North Racood watershed, most of which have higher CSR than neighboring watersheds for both scenarios. Particularly in the lower AAL watersheds, they also have lower CSR. It is challenging to justify mitigation decisions because the potential loss is estimated at up to twenty-six thousand US dollars, which is very low compared to other regions. A thorough benefit-cost assessment for the central part of the watershed is critical for mitigation decisions to lower the potential risk to Des Moines. Figure 7 delivers an overview of estimated annual flood loss and the distribution of the CSR for 2-year and 5-year flood scenarios.

The study reveals that the Skunk River and West Nishnabotna watersheds have high AAL estimates (Figure 8). The AAL estimate reached over eight million US dollars for the Skunk River and nearly seven million US dollars for the West Nishnabotna watersheds. Based on CSR analysis, the Skunk River watershed has lower CSR values in the upstream region. However, AAL estimates are also lower for those HUC-12 watersheds. So, a detailed flood mitigation study may be required 
for flood reduction in the downstream regions. Unlike the Skunk River, West Nishnabotna's HUC12 watersheds within the 2-year and 5-year flood zones show higher CSR values than any other region. Therefore, HUC-12s with the higher AAL estimates may require flood protection measures (i.e., levees) to reduce agricultural losses. To avoid more significant losses, the potential impacts of West Nishnabotna must be thoroughly investigated.
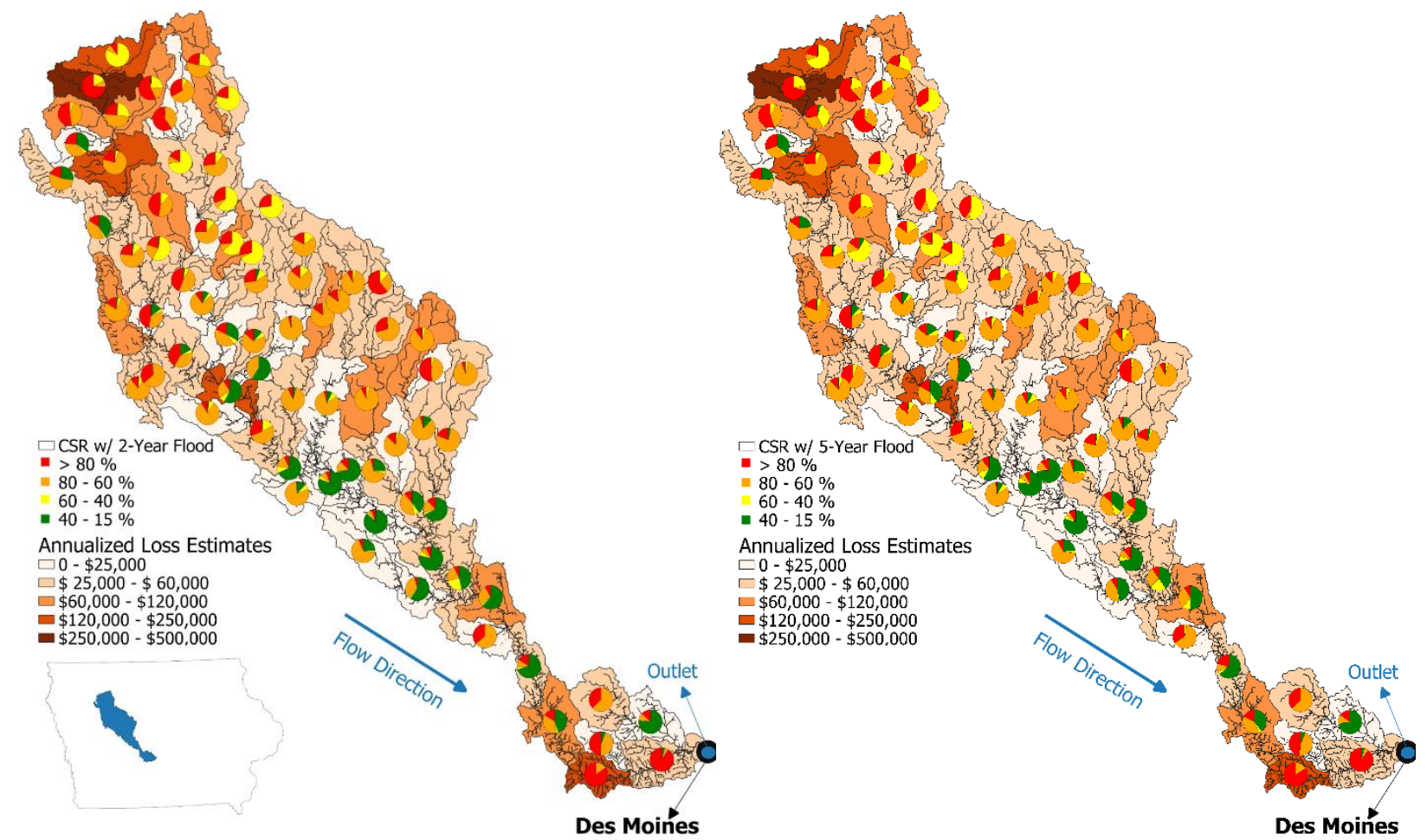

Figure 7. Distribution of CSR for 2- and 5- year flood scenario in North Racoon watershed
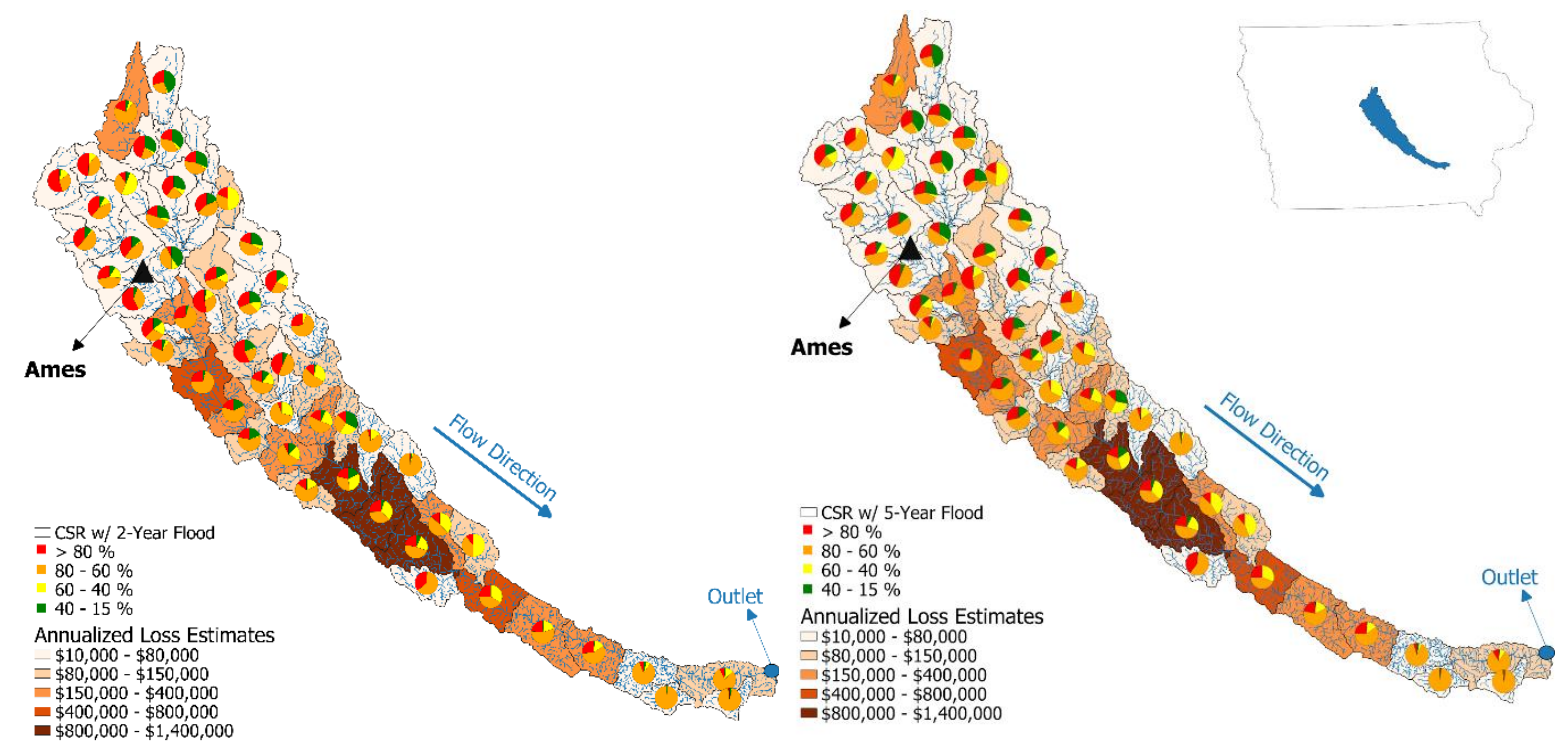

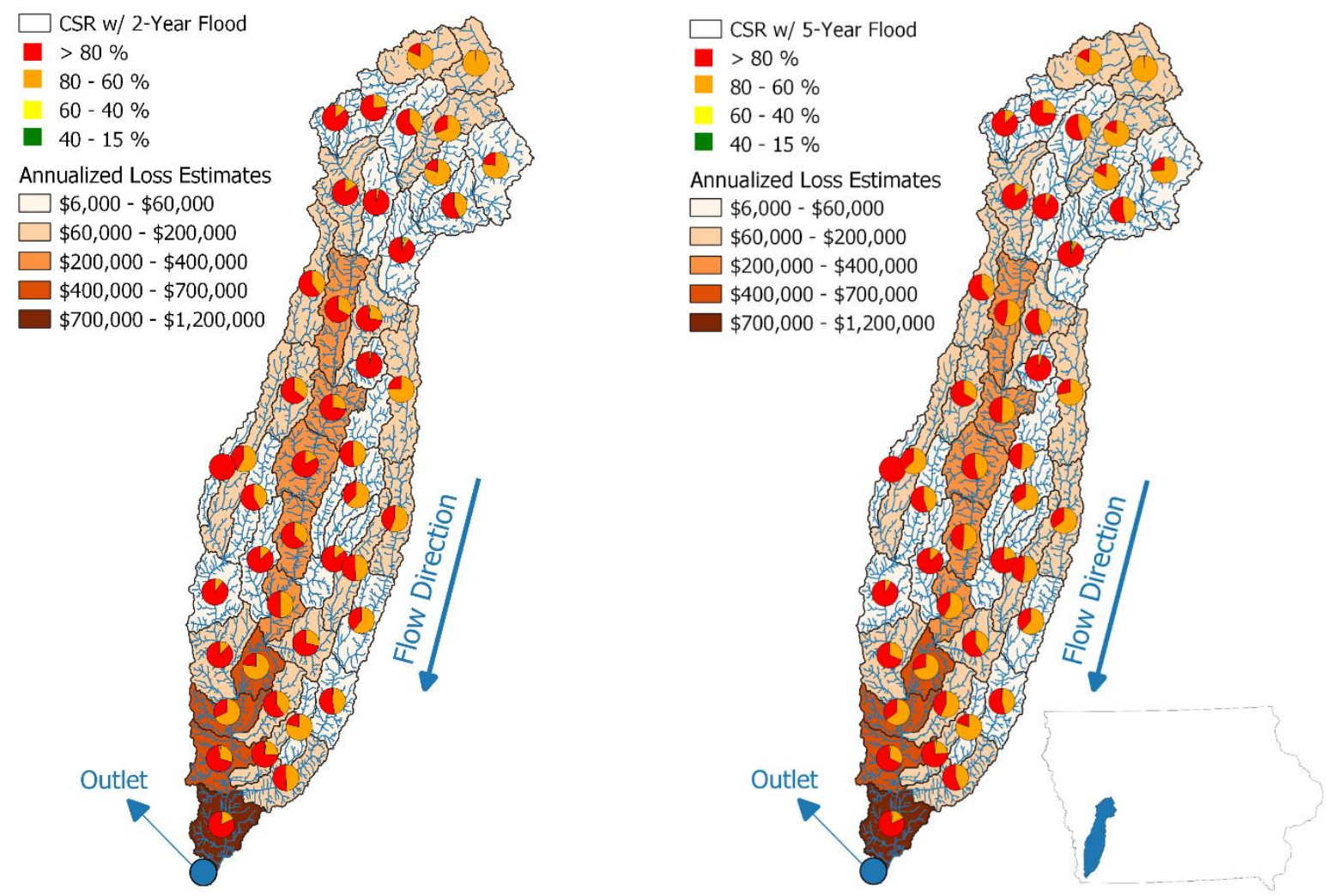

Figure 8. Distribution of CSR for 2- and 5- year flood scenario in Skunk River (Top) and West Nishnabotna (Bottom) watershed

Overall, the most vulnerable watershed regions show a promising potential for flood reduction efforts. However, these efforts must be carefully studied to evaluate the benefits and costs of the mitigation. On the other hand, fertile regions within the flood zones should be considered for flood protection measures to maintain sustainable food production. The potential impact of flood protection measures must be investigated to avoid further loss downstream.

\subsection{DEM-based Flood Map Evaluation}

Terrain-based flood model outputs were generated for a pilot region located in southeastern Iowa using a client-side rapid inundation mapping system (Hu and Demir, 2021; Li and Demir, 2021) based on Height Above Nearest Drainage (HAND) model. The model outputs were generated based on 100-year and 500-year return period flood scenarios. The pilot region has seventy-seven HUC-12 scale watersheds. Soybean is selected to estimate the inundation area using the HAND data. Then, the correlation coefficient for the whole region and the error rates for each HUC-12 are estimated with reference to FEMA outputs (See Figure 9). Overall, 0.93 and 0.94 correlations are estimated for the 100-year and 500-year scenarios, respectively. On a watershed scale, HAND outputs performed with a low error rate (between $10 \%$ to $-10 \%$ ) in the majority of the watersheds. However, the error rate is estimated to be higher for the outer regions, with up to a $40 \%$ 
overestimation and a $60 \%$ underestimation. It is important to note that the estimated inundation areas for those regions are small (10-100 acres) in both data sources. Due to lower requirements, we found that terrain-based flood models are cost-efficient and reliable ways to assess flood impact for agricultural regions.

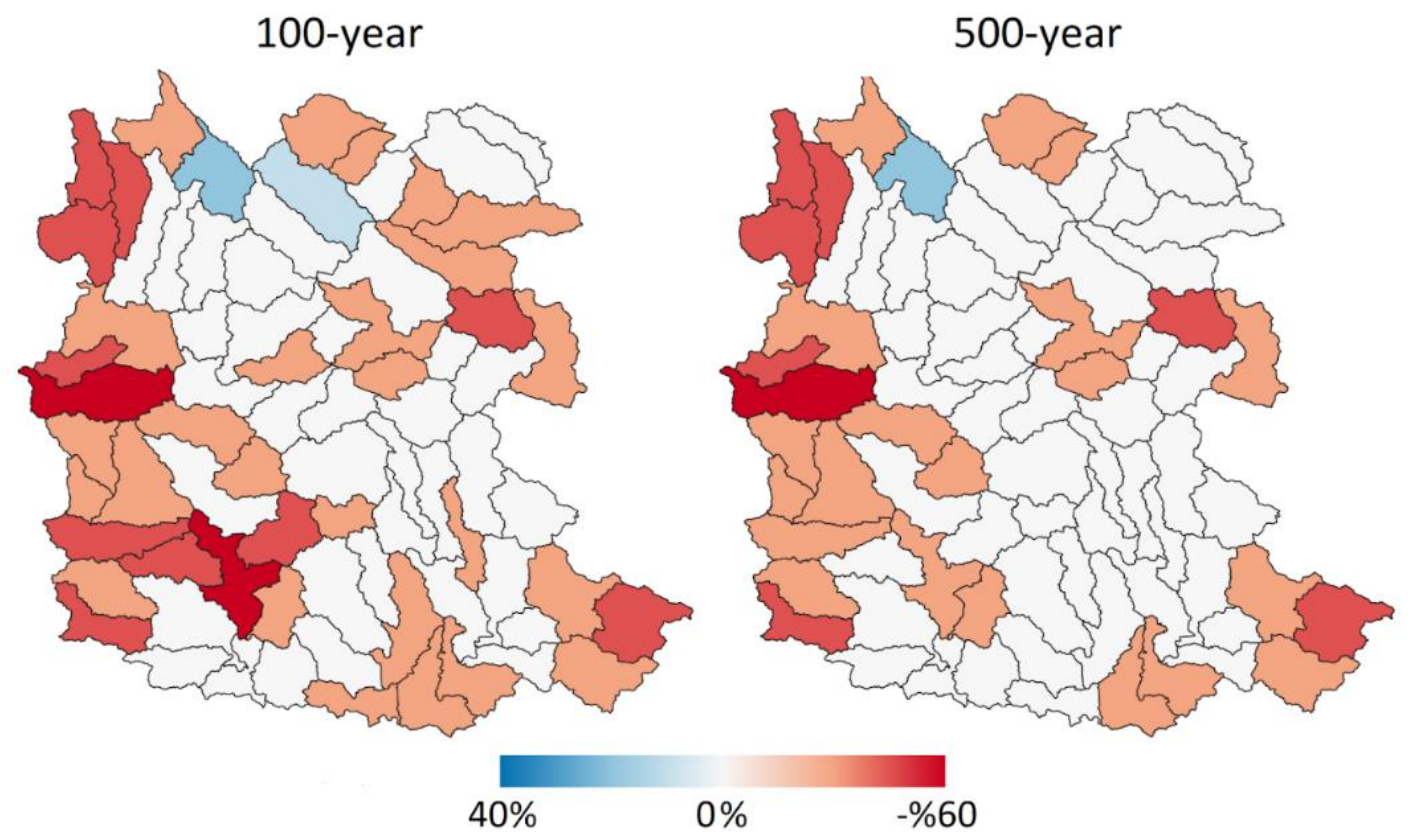

Figure 9. Error rates of HAND model output with reference to the FEMA maps for inundated area estimation of soybean fields

\section{Conclusion}

In this study, we present a comprehensive agricultural flood impact assessment in the state of Iowa. The assessment employed large-scale datasets such as statewide flood inundation maps, the most up-to-date agricultural land use data, corn suitability rate raster, and crop frequency layers. Our analysis suggests that nearly 450,000 acres of farmland are located in the 2-year flood zone, frequently prone to flood losses. The total ratio of the inundation area stays the same for each crop type and all years. The study reveals a slight variance in flood loss concerning seasons (i.e., 2016, 2017) and certain regions (i.e., HUC-8 watershed). The highest AAL is estimated for corn crops, and it is followed by soybeans. The crop frequency analysis shows that these crop types (e.g., corn, soybeans) will remain under flood threat for a while without mitigation efforts. We identified the Middle Cedar, Skunk River, North Racoon, and West Nishnabotna watersheds as the most vulnerable regions for the studied crop types (i.e., corn, soybeans, and alfalfa).

The study provides significant insights into the agricultural flood vulnerability of the state where agricultural practice is one of the core driving economic factors. The study also emphasized the importance of future mitigation assessments to ensure food security, protect jobs, and reduce potential flooding impacts for the state's urban regions. Our analysis reveals that potential flood reduction may be possible for major communities such as Des Moines, Cedar Falls, Cedar Rapids, 
This manuscript is an EarthArXiv preprint and has not been peer-reviewed before.

Subsequent versions of this manuscript may have slightly different content.

and Waterloo. Contrarily, the study also suggests corn-productive regions (e.g., West Nishnabotna), located in flood-prone regions, may need a protective measure for flooding to maintain high production. This research emphasizes the importance of the downstream impacts of possible mitigation efforts. The study also tested the terrain-based flood model (HAND) performance by estimating the inundation area, which performed well with a correlation of 0.93 for the 100-year scenario and 0.94 for the 500-year scenario.

\section{References}

Alabbad, Y., Yildirim, E., \& Demir, I. (2021). Flood Mitigation Data Analytics and Decision Support Framework: Iowa Middle Cedar Watershed Case Study. EarthArxiv, 2790.

Agliamzanov, R., Sit, M., \& Demir, I. (2020). Hydrology@ Home: a distributed volunteer computing framework for hydrological research and applications. Journal of Hydroinformatics, 22(2), 235-248.

Aich, V., Liersch, S., Vetter, T., Fournet, S., Andersson, J. C., Calmanti, S., ... \& Paton, E. N. (2016). Flood projections within the Niger River Basin under future land use and climate change. Science of the Total Environment, 562, 666-677.

Anderson, B. G., Rutherfurd, I. D., \& Western, A. W. (2006). An analysis of the influence of riparian vegetation on the propagation of flood waves. Environmental Modelling \& Software, 21(9), 1290-1296.

Antolini, F., Tate, E., Dalzell, B., Young, N., Johnson, K., \& Hawthorne, P. L. (2020). Flood risk reduction from agricultural best management practices. JAWRA Journal of the American Water Resources Association, 56(1), 161-179.

Apollonio, C., Balacco, G., Novelli, A., Tarantino, E., \& Piccinni, A. F. (2016). Land use change impact on flooding areas: The case study of Cervaro Basin (Italy). Sustainability, 8(10), 996.

Balana, B. B., Sanfo, S., Barbier, B., Williams, T., \& Kolavalli, S. (2019). Assessment of flood recession agriculture for food security in Northern Ghana: An optimization modelling approach. Agricultural Systems, 173, 536-543.

Beddington, J. R., Asaduzzaman, M., Bremauntz, F. A., Clark, M. E., Guillou, M., Jahn, M. M., ... \& Wakhungu, J. (2012). Achieving food security in the face of climate change: Final report from the Commission on Sustainable Agriculture and Climate Change.

Benito, G., Rico, M., Sánchez-Moya, Y., Sopeña, A., Thorndycraft, V. R., \& Barriendos, M. (2010). The impact of late Holocene climatic variability and land use change on the flood hydrology of the Guadalentín River, southeast Spain. Global and Planetary Change, 70(1-4), 53-63.

Borrelli, P., Robinson, D. A., Fleischer, L. R., Lugato, E., Ballabio, C., Alewell, C., ... \& Panagos, P. (2017). An assessment of the global impact of 21 st century land use change on soil erosion. Nature communications, 8(1), 1-13.

Brémond, P., Grelot, F., \& Agenais, A. L. (2013). Economic evaluation of flood damage to agriculture-review and analysis of existing methods. Natural Hazards and Earth System Sciences, 13(10), 2493-2512. 
This manuscript is an EarthArXiv preprint and has not been peer-reviewed before.

Subsequent versions of this manuscript may have slightly different content.

Bruzzone, S. (2013). Climate change and reorganizing land use: Flood control areas as a network effect. International Journal of Urban and Regional Research, 37(6), 2001-2013.

Boryan, C. G., Yang, Z., \& Willis, P. (2014, August). US geospatial crop frequency data layers. In 2014 The Third International Conference on Agro-Geoinformatics (pp. 1-5). IEEE.

Crane-Droesch, B. A., Marshall, E., Rosch, S., Riddle, A., Cooper, J., \& Wallander, S. (2019). Climate change and agricultural risk management into the 21st century. Economic Research Report-Economic Research Service, USDA, (266).

Crow, H. A. (2014). Assessment of the FEMA HAZUS-MH 2.0 crop loss tool Fremont County, Iowa 2011. University of Southern California. Master Thesis.

Del Ninno, C., Dorosh, P. A., \& Smith, L. C. (2003). Public policy, markets and household coping strategies in Bangladesh: Avoiding a food security crisis following the 1998 floods. World development, 31(7), 1221-1238.

Downton, M. W., \& Pielke, R. A. (2005). How accurate are disaster loss data? The case of US flood damage. Natural Hazards, 35(2), 211-228.

Dutta, D., Herath, S., \& Musiake, K. (2003). A mathematical model for flood loss estimation. Journal of hydrology, 277(1-2), 24-49.

Ebert-Uphoff, I., Thompson, D.R., Demir, I., Gel, Y.R., Karpatne, A., Guereque, M., Kumar, V., Cabral-Cano, E. and Smyth, P., (2017). A vision for the development of benchmarks to bridge geoscience and data science. In 17th International Workshop on Climate Informatics.

Ewing, G., \& Demir, I. (2021). An ethical decision-making framework with serious gaming: a smart water case study on flooding. Journal of Hydroinformatics, 23(3), 466-482.

FAO. (2021). The impact of disasters and crises on agriculture and food security: 2021. Rome. https://doi.org/10.4060/cb3673en

Federal Emergency Management Agency (FEMA). (2021) Disaster Declarations for States and Counties. https://www.fema.gov/data-visualization/disaster-declarations-states-and-counties Accessed June 2021

Gambolati, G., Putti, M., Teatini, P., \& Stori, G. G. (2006). Subsidence due to peat oxidation and impact on drainage infrastructures in a farmland catchment south of the Venice Lagoon. Environmental Geology, 49(6), 814-820.

Gilles, D., Young, N., Schroeder, H., Piotrowski, J., \& Chang, Y. J. (2012). Inundation mapping initiatives of the Iowa Flood Center: Statewide coverage and detailed urban flooding analysis. Water, 4(1), 85-106.

Haltas, I., Yildirim, E., Oztas, F., \& Demir, I. (2021). A comprehensive flood event specification and inventory: 1930-2020 Turkey case study. International Journal of Disaster Risk Reduction, 56, 102086.

Han, W., Yang, Z., Di, L., \& Mueller, R. (2012). CropScape: A Web service based application for exploring and disseminating US conterminous geospatial cropland data products for decision support. Computers and Electronics in Agriculture, 84, 111-123.

Hornbuckle, B., Walker, V., Eichinger, B., Wallace, V., \& Yildirim, E. (2017, July). Soil surface roughness observed during SMAPVEX16-IA and its potential consequences for SMOS and 
This manuscript is an EarthArXiv preprint and has not been peer-reviewed before.

Subsequent versions of this manuscript may have slightly different content.

SMAP. In 2017 IEEE International Geoscience and Remote Sensing Symposium (IGARSS) (pp. 2027-2030). IEEE.

Houghton, R. A., House, J. I., Pongratz, J., Van Der Werf, G. R., Defries, R. S., Hansen, M. C., ... \& Ramankutty, N. (2012). Carbon emissions from land use and land-cover change. Biogeosciences, 9(12), 5125-5142.

Hazarika, N., Das, A. K., \& Borah, S. B. (2015). Assessing land-use changes driven by river dynamics in chronically flood affected Upper Brahmaputra plains, India, using RS-GIS techniques. The Egyptian Journal of Remote Sensing and Space Science, 18(1), 107-118.

Hu, A., \& Demir, I. (2021). Real-Time Flood Mapping on Client-Side Web Systems Using HAND Model. Hydrology, 8(2), 65.

Johanns, A. (2021a) Iowa Cash Corn and Soybean Prices-2021. File A2-11. Iowa State University Extension, Ames, Iowa. https://www.extension.iastate.edu/agdm/crops/pdf/a1 12.pdf. Accessed March 2021

Johanns, A. (2021b) Iowa Cash Corn and Soybean Prices-2021. File A2-11. Iowa State University Extension, Ames, Iowa. https://www.extension.iastate.edu/agdm/crops/pdf/a211.pdf. Accessed March 2021

Johnston, C. A. (2013). Wetland losses due to row crop expansion in the Dakota Prairie Pothole Region. Wetlands, 33(1), 175-182.

Lee, Y., \& Brody, S. D. (2018). Examining the impact of land use on flood losses in Seoul, Korea. Land use policy, 70, 500-509.

Li, Z., Mount, J., \& Demir, I. (2020). Model Parameter Evaluation and Improvement for RealTime Flood Inundation Mapping Using HAND Model: Iowa Case Study, EarthArxiv, 127.

Mallakpour, I., \& Villarini, G. (2015). The changing nature of flooding across the central United States. Nature Climate Change, 5(3), 250-254.

Meyfroidt, P., Lambin, E. F., Erb, K. H., \& Hertel, T. W. (2013). Globalization of land use: distant drivers of land change and geographic displacement of land use. Current Opinion in Environmental Sustainability, 5(5), 438-444.

Morris, J., \& Hess, T. M. (1988). Agricultural flood alleviation benefit assessment: a case study. Journal of agricultural Economics, 39(3), 402-412.

NASS. (2020). $2020 \quad$ State Agriculture Overview. https://www.nass.usda.gov/Quick_Stats/Ag_Overview/stateOverview.php?state=IOWA Accessed June 2021

Navarathinam, K., Gusyev, M., Hasegawa, A., Magome, J., \& Takeuchi, K. (2015, November). Agricultural flood and drought risk reduction by a proposed multi-purpose dam: A case study of the Malwathoya River Basin, Sri Lanka. In Proceedings of the 21st International Congress on Modelling and Simulation (MODSIM 2015), November 29th-December 4th, Queensland, Australia (pp. 1600-1606).

Olson, K. R., \& Morton, L. W. (2012). The impacts of 2011 induced levee breaches on agricultural lands of Mississippi River Valley. Journal of Soil and Water Conservation, 67(1), 5A-10A. 
This manuscript is an EarthArXiv preprint and has not been peer-reviewed before.

Subsequent versions of this manuscript may have slightly different content.

Oskorouchi, H. R., \& Sousa-Poza, A. (2021). Floods, food security, and coping strategies: Evidence from Afghanistan. Agricultural Economics, 52(1), 123-140.

Rahman, M. S., \& Di, L. (2020). A systematic review on case studies of remote-sensing-based flood crop loss assessment. Agriculture, 10(4), 131.

Rahman, M. S., Di, L., Shrestha, R., Eugene, G. Y., Lin, L., Zhang, C., ... \& Yang, Z. (2017, August). Agriculture flood mapping with Soil Moisture Active Passive (SMAP) data: A case of 2016 Louisiana flood. In 2017 6th International Conference on Agro-Geoinformatics (pp. 1-6). IEEE.

Risk Management Agency (RMA). (2021) Summary of Business Report for 2018 thru 2021. https://www3.rma.usda.gov/apps/sob/current_week/sobrpt2018-2021.pdf Accessed June 2021

Plastina, A. (2021) Estimated costs of crop production in Iowa-2021. File A1-20. Iowa State University Extension, Ames, Iowa. http://www.extension.iastate.edu/agdm/crops/pdf/a120.pdf. Accessed March 2021

Plastina A., and Leibold, K. (2019) ARC-CO \& PLC Per Non-Irrigated Acre Payment Estimator for Iowa, 2021-22. Iowa State University Extension, Ames, Iowa. https://www.extension.iastate.edu/agdm/crops/html/a1-33.html. Accessed March 2021

Plastina, A. and Leibold K. (2021) ARC-CO/PLC Payments by Crop and County for Iowa, 20142018. Iowa State University Extension, Ames, Iowa. https://www.extension.iastate.edu/agdm/crops/html/a1-33.html. Accessed March 2021

Posthumus, H., Morris, J., Hess, T. M., Neville, D., Phillips, E., \& Baylis, A. (2009). Impacts of the summer 2007 floods on agriculture in England. Journal of Flood Risk Management, 2(3), 182-189.

Sarmiento, C., \& Miller, T. R. (2006). Costs and consequences of flooding and the impact of the National Flood Insurance Program. Pacific Institute for Research and Evaluation. Calverton, Maryland.

Schilling, K. E., Gassman, P. W., Kling, C. L., Campbell, T., Jha, M. K., Wolter, C. F., \& Arnold, J. G. (2014). The potential for agricultural land use change to reduce flood risk in a large watershed. Hydrological processes, 28(8), 3314-3325.

Secchi, S., Gassman, P. W., Williams, J. R., \& Babcock, B. A. (2009). Corn-based ethanol production and environmental quality: a case of Iowa and the Conservation Reserve Program. Environmental management, 44(4), 732-744.

Sermet, Y., Demir, I., \& Muste, M. (2020). A serious gaming framework for decision support on hydrological hazards. Science of The Total Environment, 728, 138895.

Sit, M., Sermet, Y., \& Demir, I. (2019). Optimized watershed delineation library for server-side and client-side web applications. Open Geospatial Data, Software and Standards, 4(1), 1-10.

Slater, L. J., \& Villarini, G. (2016). Recent trends in U.S. flood risk. Geophysical Research Letters, 43(24), 12-428.

Slater, L. J., Villarini, G., Bradley, A. A., \& Vecchi, G. A. (2019). A dynamical statistical framework for seasonal streamflow forecasting in an agricultural watershed. Climate Dynamics, 53(12), 7429-7445. 
Tapia-Silva, F. O., Itzerott, S., Foerster, S., Kuhlmann, B., \& Kreibich, H. (2011). Estimation of flood losses to agricultural crops using remote sensing. Physics and Chemistry of the Earth, Parts A/B/C, 36(7-8), 253-265.

Teague, A., Sermet, Y., Demir, I., \& Muste, M. (2021). A collaborative serious game for water resources planning and hazard mitigation. International Journal of Disaster Risk Reduction, 53, 101977.

Thomas, N. W. (2015). Simulating the hydrologic impact of distributed flood mitigation practices, tile drainage, and terraces in an agricultural catchment. Doctorate Dissertation. The University of Iowa.

Tran, D. D., van Halsema, G., Hellegers, P. J., Ludwig, F., \& Seijger, C. (2018). Stakeholders' assessment of dike-protected and flood-based alternatives from a sustainable livelihood perspective in An Giang Province, Mekong Delta, Vietnam. Agricultural Water Management, 206, 187-199.

Tripathi, R., Sengupta, S. K., Patra, A., Chang, H., \& Jung, I. W. (2014). Climate change, urban development, and community perception of an extreme flood: A case study of Vernonia, Oregon, USA. Applied Geography, 46, 137-146.

USACE. 1985. "AGDAM, Agricultural Flood Damage Analysis, User's Manual." Hydrologic Engineering Center, WaterResources Support Center, U.S. Army Corps of Engineers.

USDA. (2021a) Iowa Ag News - 2020 Corn County Estimates. https://www.nass.usda.gov/Statistics_by_State/Iowa/Publications/County_Estimates/2021/IA -CtyEst-Corn-02-21.pdf Accessed March 2021

USDA. (2021b) Iowa Ag News - 2020 Corn County Estimates. https://www.nass.usda.gov/Statistics_by_State/Iowa/Publications/County_Estimates/2021/IA -CtyEst-Soybeans-02-21.pdf Accessed March 2021

USDA. (2021c) Iowa Ag News - 2020 Corn County Estimates. https://www.nass.usda.gov/Statistics_by_State/Iowa/Publications/County_Estimates/2019/IA -CtyEst-Hay-17-18.pdf Accessed March 2021

Vahedifard, F., AghaKouchak, A., \& Jafari, N. H. (2016). Compound hazards yield Louisiana flood. Science, 353(6306), 1374-1374.

Wehmeyer, L. L., Weirich, F. H., \& Cuffney, T. F. (2011). Effect of land cover change on runoff curve number estimation in Iowa, 1832-2001. Ecohydrology, 4(2), 315-321.

West, T. L. (2010). Flood Mitigation and Response: Comparing the Great Midwest Floods of 1993 and 2008. Master's Thesis. Naval Postgraduate School Monterey CA.

Wheater, H., \& Evans, E. (2009). Land use, water management and future flood risk. Land use policy, 26, S251-S264.

Xu, H., Demir, I., Koylu, C., \& Muste, M. (2019). A web-based geovisual analytics platform for identifying potential contributors to culvert sedimentation. Science of the Total Environment, 692, 806-817. 
Xu, H., Windsor, M., Muste, M., \& Demir, I. (2020). A web-based decision support system for collaborative mitigation of multiple water-related hazards using serious gaming. Journal of environmental management, 255, 109887.

Yildirim, E., \& Demir, I. (2019). An integrated web framework for HAZUS-MH flood loss estimation analysis. Natural Hazards, 99(1), 275-286.

Yildirim, E., \& Demir, I. (2021). An Integrated Flood Risk Assessment and Mitigation Framework: A Case Study for Middle Cedar River Basin, Iowa, US. International Journal of Disaster Risk Reduction, 56, 102113.

Yildirim, E., (2017). Hazus-MH flood loss estimation on a Web-based system. Master's Thesis. University of Iowa. 